\title{
Density Gradient Centrifugation Pra-freezing Mengoptimalkan Persentase Morfologi Normal Spermatozoa Pasca-thawing
}

\author{
Seso Sulijaya Suyono, ${ }^{1}$ Aucky Hinting, ${ }^{1,2}$ Hamdani Lunardhi, ${ }^{1,2}$ Reny I'tishom ${ }^{3}$ \\ ${ }^{1}$ Program Studi Spesialis Andrologi Fakultas Kedokteran Universitas Airlangga, Surabaya, Indonesia, \\ ${ }^{2}$ Klinik Fertilitas RSIA Ferina Surabaya, Indonesia, ${ }^{3}$ Departemen Biologi Kedokteran Fakultas Kedokteran \\ Universitas Airlangga Surabaya, Indonesia
}

\begin{abstract}
Abstrak
Kriopreservasi akan mengganggu struktur dan fungsi spermatozoa. Preparasi semen mampu menghasilkan spermatozoa dengan kualitas baik. Penelitian ini bertujuan menganalisis pengaruh preparasi semen dengan density gradient centrifugation (DGC) pra-freezing terhadap kualitas spermatozoa pasca-thawing. Penelitian dilakukan di boratorium Biologi Kedokteran, Fakultas Kedokteran Universitas Airlangga periode November 2017-Januari 2018. Penelitian eksperimental laboratoris dilakukan menggunakan cairan ejakulat volunter pria infertil. Semua sampel dibagi menjadi dua bagian, kelompok kontrol serta kelompok perlakuan berupa preparasi mini DGC. Setelah penambahan krioprotektan, selanjutnya dilakukan freezing. Pemeriksaan kualitas spermatozoa, meliputi motilitas, viabilitas serta persentase morfologi normal menggunakan metode WHO 2010, baik pra-freezing maupun pasca-thawing. Persentase perubahan kualitas spermatozoa pasca-thawing kedua kelompok dibandingkan menggunakan uji $t$ dan bermakna jika nilai $p<0,05$. Total 20 sampel cairan ejakulat digunakan dalam penelitian ini. Persentase penurunan motilitas progresif, motilitas total, serta viabilitas pascathawing antara kedua kelompok tidak berbeda bermakna dengan nilai p masing-masing 0,422; 0,873 serta 0,432 . Namun, penurunan persentase morfologi normal pasca-thawing pada kelompok kontrol jauh lebih besar daripada kelompok perlakuan dengan nilai $p<0,001$. Penelitian ini menyimpulkan bahwa preparasi semen berupa mini DGC pra-freezing mampu menghasilkan spermatozoa pasca-thawing dengan persentase morfologi normal yang lebih baik daripada protokol direct freezing.
\end{abstract}

Kata kunci: Density gradient, freezing, spermatozoa, thawing

\section{Pre-freezing Density Gradient Centrifugation Optimizes the Percentage of Post-thawed Sperms with Normal Morphology}

\begin{abstract}
Cryopreservation impairs sperm structure and functions. Sperm preparation is a selection technique to obtain a population of high quality sperms. This study aimed to analyze the effect of pre-freezing Density Gradient Centrifugation (DGC) sperm preparation on the quality of post-thawed sperms. An experimental laboratory study was conducted using the ejaculates collected from volunteers visiting to our department. Samples were split into two fractions: control group and treatment group. In the treated group, mini-DGC sperm preparations were developed. After some cryoprotectants were added, samples were then cryopreserved using rapid freezing protocol. The evaluation of sperm quality that included evaluation on motility, viability and percentage of sperm morphology was performed by referring to 2010 WHO standardization on semen analysis. Evaluation was performed under pre-freezing and post-thawed condition. The percentage of sperm parameter changes between the two groups were compared using t-test with p-value $<0.05$ considered statistically significant. A total of 20 samples were included in this study. Post-thawed progressive motility, total motility, and viability considerably declined between two groups with p-values of $0.422,0.873$, and 0.432 respectively. In post-thawed observation, the percentage of sperms with normal morphology was significantly lower in the control group when compared to the treatment group $(\mathrm{p}<0.001)$. In conclusion, the pre-freezing mini-DGC can optimize the post-thawed percentage of sperms with normal morphology compared to direct freezing protocol.
\end{abstract}

Key words: Density gradient, freezing, sperm, thawing

Korespondensi: Seso Sulijaya Suyono, dr., Sp.And, Program Studi Spesialis Andrologi Fakultas Kedokteran Universitas Airlangga, Surabaya, Jawa Timur, Email: suyono.sesosulijaya@gmail.com; ritishom@fk.unair.ac.id 


\section{Pendahuluan}

Infertilitas masih menjadi masalah di seluruh dunia dengan angka kejadiannya yang cenderung meningkat yakni sekitar 10-15\% pasangan usia reproduksi. Hal ini menyebabkan permintaan akan fasilitas teknik reproduksi berbantu (TRB) sebagai penatalaksanaan kasus infertilitas juga turut meningkat. Kriopreservasi merupakan salah satu teknik TRB yang terintegrasi. ${ }^{1}$

Kriopreservasi memungkinkan penyimpanan sel pada suhu ekstrem rendah dalam jangka waktu yang lama. ${ }^{2}$ Kriopreservasi spermatozoa pada umumnya digunakan sebelum dilakukan kemoterapi atau radioterapi, pada kasus oligoasthenoteratozoospermia (OAT) yang berat, gangguan ejakulasi serta pada kasus donor spermatozoa. ${ }^{3}$ Prosedur kriopreservasi yang terdiri atas prosedur freezing dan thawing akan memberikan efek merugikan terhadap struktur dan fungsi spermatozoa, ${ }^{4}$ yakni meningkatkan persentase spermatozoa dengan motilitas yang buruk dan morfologi abnormal, ${ }^{5,6}$ menginduksi dekondensasi kromatin, serta meningkatkan fragmentasi DNA spermatozoa. ${ }^{7}$

Teknik freezing yang digunakan saat ini dapat dibedakan menjadi teknik freezing konvensional dan teknik freezing mutakhir. Teknik freezing konvensional terdiri atas slow freezing, rapid freezing, serta ultra-rapid freezing. Teknik freezing mutakhir adalah vitrifikasi. ${ }^{2}$ Meskipun vitrifikasi tampak sederhana, namun pada praktiknya vitrifikasi spermatozoa tidak lebih efektif daripada teknik freezing konvensional karena ketidakmampuan kita membekukan spermatozoa secepat-cepatnya hingga vitrifikasi spermatozoa dapat terjadi. ${ }^{1}$

Kualitas spermatozoa pasca-thawing dapat dioptimalkan melalui medium krioprotektan yang dipakai, laju penurunan suhu saat freezing, suhu penyimpanan sampel, teknik thawing, ${ }^{8}$ serta dapat meningkatkan kualitas spermatozoa pra-freezing. ${ }^{9}$ Preparasi semen sebagai teknik seleksi spermatozoa yang mampu menghasilkan spermatozoa motil dengan kualitas baik. Preparasi semen yang dilakukan ialah sebagai bagian dari kriopreservasi diharapkan dapat meningkatkan survival spermatozoa pascathawing. ${ }^{5}$

Terdapat beberapa teknik seleksi dari spermatozoa atau preparasi semen yang dikenal, yakni teknik simple washing, swim-up, density gradient, magnetic assissted cell sorting (MACS), zeta potential, serta elektroforesis. Namun demikian, teknik swim-up dan density gradient merupakan dua teknik seleksi spermatozoa yang paling umum digunakan. ${ }^{10}$ Pemilihan teknik seleksi spermatozoa yang digunakan bergantung pada kualitas dari sampel. Pada sampel dengan konsentrasi, motilitas serta morfologi yang normal, teknik simple washing atau teknik swim-up lebih direkomendasikan. Namun, pada sampel dengan kualitas yang suboptimal seperti pada pasien infertil maka teknik density gradient centrifugation lebih sering digunakan. ${ }^{11}$

Penelitian mengenai efektivitas preparasi semen sebelum proses kriopreservasi telah melaporkan hasil yang beragam. Terdapat dua protokol kriopreservasi berkaitan dengan preparasi semen, yakni protokol direct freezing dan protokol preparasi pra-freezing. Donnelly $d k k^{5}$ melaporkan kriopreservasi spermatozoa yang tercampur di dalam plasma semen meningkatkan motilitas dan integritas DNA pasca-thawing. Penelitian lain menyimpulkan bahwa preparasi semen dengan metode swimup sebelum freezing akan meningkatkan kualitas spermatozoa pasca-thawing. ${ }^{6}$ Fabozzi dkk. ${ }^{12}$ telah menyimpulkan bahwa protokol direct-freezing memberikan hasil tuaian dengan viabilitas spermatozoa yang lebih baik, namun motilitas yang sama apabila dibanding dengan protokol preparasi pra-freezing.

Tujuan penelitian ini menganalisis pengaruh preparasi semen, yakni dengan density gradient centrifugation pra-freezing terhadap kualitas spermatozoa pasca-thawing yang terdiri atas parameter motilitas, viabilitas, serta persentase morfologi normal.

\section{Metode}

Penelitian ini adalah penelitian eksperimental laboratoris dengan pre and post test control group design. Penelitian dilaksanakan di Laboratorium Biologi Kedokteran, Fakultas Kedokteran Universitas Airlangga periode November 2017 hingga Januari 2018. Sampel penelitian ini adalah cairan ejakulat pria infertil yang datang secara sukarela ke Departemen Biologi Kedokteran Fakultas Kedokteran Universitas Airlangga dan bersedia ikut serta dalam penelitian dengan menandatangani persetujuannya (informed consent). Penelitian ini telah disetujui oleh Komite Etik Penelitian Kesehatan Fakultas Kedokteran Universitas Airlangga dengan surat keterangan kelaikan etik No. 308/EC/KEPK/ FKUA/2017.

Semua sampel cairan ejakulat dengan volume $\geq 2$ cc serta total spermatozoa motil $>10$ juta diikutsertakan di dalam peneltian ini. Sampel 
cairan ejakulat dengan hasil analisis semen hematospermia (terdapat eritrosit atau sel darah merah dalam cairan ejakulat) serta leukospermia (jumlah leukosit > 1 juta/cc) dieksklusikan dari penelitian ini.

Analisis semen untuk menilai suatu kualitas spermatozoa, yakni motilitas, viabilitas, serta persentase morfologi dilakukan menggunakan standar WHO tahun 2010. Analisis semen dilakukan oleh dua orang kompeten yang sudah memperoleh sertifikat standardisasi analisis semen dan dikeluarkan oleh Perhimpunan Dokter Spesialis Andrologi Indonesia (PERSANDI).

Setelah dilakukan analisis semen awal, selanjutnya sampel cairan ejakulat akan dibagi menjadi dua bagian, yakni kontrol dan perlakuan. Pada fraksi sampel yang merupakan fraksi perlakuan, dilakukan preparasi semen dengan teknik mini density gradient centrifugation (miniDGC) sesuai dengan protokol (SpermGrad ${ }^{\mathrm{TM}}$, SpermRinse ${ }^{\mathrm{TM}}$, Vitrolife Inc.).

Selanjutnya, pada kedua fraksi sampel dilakukan prosedur freezing dengan langkahlangkah sebagai berikut: sebanyak 0,5 mL fraksi sampel diencerkan dengan 0,5 mL krioprotektan (SpermFreeze $^{\mathrm{TM}}$, Vitrolife Inc.) dengan perbandingan 1:1 secara perlahan-lahan tetes demi tetes hingga homogen, selanjutnya tunggu hingga campuran fraksi sampel-krioprotektan mencapai ekuilibrasi (10 menit). Setelah mencapai ekuilibrasi, lalu lakukan pengemasan sampel ke dalam straw (jerami plastik) dengan ukuran 0,5 mL (Cassou straw). Straw yang telah terisi sampel selanjutnya diletakkan di atas uap nitrogen cair $\left(\mathrm{LN}_{2}\right)$ dengan jarak $3 \mathrm{~cm}$ dari permukaan $\mathrm{LN}_{2}$ dan biarkan selama 30 menit. Setelah 30 menit, straw dicelupkan langsung ke dalam cairan $\mathrm{LN}_{2}$ (suhu $-196^{\circ} \mathrm{C}$ ). Untuk memudahkan penyimpanan di dalam tangki $\mathrm{LN}_{2}$, straw dimasukkan ke dalam cryocassette. Penyimpanan pada suhu kriogenik dalam cairan $\mathrm{LN}_{2}$ dapat bertahan dalam jangka waktu yang tidak terbatas, namun pada penelitian ini sampel disimpan dalam cairan $\mathrm{LN}_{2}$ selama 24 jam.

Prosedur thawing sampel sendiri dilakukan dengan langkah-langkah sebagai berikut: straw yang berisi cairan sampel dikeluarkan dari cryocasette dan selanjutnya dihangatkan menggunakan waterbath dengan suhu $37^{\circ} \mathrm{C}$ selama 30 detik dan selanjutnya dibiarkan pada suhu kamar selama 20 menit untuk kemudian dilakukan evaluasi kualitas spermatozoa pascathawing yang meliputi motilitas, viabilitas, serta persentase morfologi normal menggunakan standar WHO tahun 2010.

Variabel persentase perubahan kualitas spermatozoa diperoleh dari selisih antara parameter pasca-thawing dan parameter prafreezing baik motilitas, viabilitas, serta persentase morfologi normal spermatozoa. Selanjutnya dibanding dengan parameter pra-freezing dan dinyatakan dalam persen. Persentase perubahan kualitas spermatozoa kelompok kontrol bila dibandingkan dengan persentase perubahan kualitas spermatozoa kelompok perlakuan miniDGC pra-freezing dan dianalisis menggunakan uji t. Analisis statistik menggunakan perangkat lunak SPSS 21. Perbedaan dianggap bermakna jika nilai $\mathrm{p}<0,05$.

\section{Hasil}

Total terdapat 22 sampel cairan ejakulat selama periode penelitian November 2017 hingga Januari 2018, namun hanya 20 sampel cairan ejakulat yang diikutsertakan ke dalam penelitian. Dua sampel tidak diikutsertakan pada penelitian karena total spermatozoa motil cairan ejakulat kurang dari 10 juta. Dari hasil analisis semen 20 sampel cairan ejakulat tersebut didapatkan rentang konsentrasi sperma 12-122 juta/mL dengan rerata sebesar $39 \pm, 6$ juta/mL. Hal ini menunjukkan bahwa sampel cairan ejakulat yang diikutsertakan dalam penelitian ini mempunyai konsentrasi spermatozoa yang cukup heterogen.

Data kualitas spermatozoa yang meliputi paramater motilitas, viabilitas, serta persentase morfologi normal baik pada kondisi awal (prafreezing) maupun kondisi pasca thawing kedua kelompok, yakni kelompok kontrol (protokol direct freezing) dan juga kelompok perlakuan (preparasi mini-DGC pra-freezing) dapat dirangkum pada Tabel 1.

Motilitas spermatozoa pasca-thawing itu menurun secara signifikan apabila dibanding dengan data motilitas spermatozoa prafreezing. Sampel pada kelompok kontrol juga mempunyai persentase spermatozoa pascathawing dengan motilitas progresif dengan rerata $19,3 \pm 6,3 \%$ serta motilitas total dengan rerata $39 \pm 9,4 \%$. Kelompok perlakuan memiliki rerata motilitas progresif sebesar 18,3 $\pm 7,1 \%$ serta rerata motilitas total sebesar $39,7 \pm 10,6 \%$. Data motilitas spermatozoa pasca-thawing pada kedua kelompok ini lebih rendah secara signifikan bila dibanding dengan data motilitas spermatozoa pra-freezing $\mathrm{p}<0,001$. Namun, data motilitas (motilitas progresif serta motilitas total) pasca-thawing antara kedua kelompok tidak berbeda bermakna dengan nilai $p=0,624$ dan 0,839 . 


\begin{tabular}{|c|c|c|c|c|c|c|}
\hline $\begin{array}{l}\text { Parameter } \\
\text { Spermatozoa }\end{array}$ & Pra-freezing & $\begin{array}{c}\text { Pasca-thawing } \\
\text { Kelompok } \\
\text { Kontrol }\end{array}$ & $\begin{array}{c}\text { Pasca-thawing } \\
\text { Kelompok } \\
\text { Preparasi } \\
\text { Mini-DGC Pra- } \\
\text { freezing }\end{array}$ & $\mathrm{p}^{\mathrm{a}}$ & Nilai $\mathbf{p}^{*}$ & $\mathrm{p}^{\mathrm{c}}$ \\
\hline \multicolumn{7}{|l|}{ Motilitas (\%) } \\
\hline Progresif & $41,3 \pm 9,2$ & $19,3 \pm 6,3$ & $18,3 \pm 7,1$ & $<0,001$ & $<0,001$ & 0,624 \\
\hline Nonprogresif & $19,4 \pm 3,9$ & $19,8 \pm 4,6$ & $21,5 \pm 6,5$ & 0,824 & 0,324 & 0,343 \\
\hline Motilitas total & $60,7 \pm 9,2$ & $39,1 \pm 9,4$ & $39,7 \pm 10,6$ & $<0,001$ & $<0,001$ & 0,839 \\
\hline Imotil & $39,3 \pm 9,2$ & $61 \pm 9,4$ & $60,3 \pm 10,6$ & $<0,001$ & $<0,001$ & 0,839 \\
\hline Viabilitas (\%) & $71,2 \pm 9,8$ & $44,8 \pm 9,4$ & $42,6 \pm 11,1$ & $<0,001$ & $<0,001$ & 0,503 \\
\hline Morfologi (\%) & $12 \pm 3,8$ & $9,7 \pm 3,5$ & $11,9 \pm 4,2$ & $<0,001$ & 0,830 & 0,074 \\
\hline
\end{tabular}

Keterangan: $p^{a}$ : uji t berpasangan antara data pra-freezing dan data pasca-thawing pada kelompok kontrol; $\mathrm{p}^{\mathrm{b}}$ : uji t berpasangan antara data pra-freezing dan data pasca-thawing pada kelompok perlakuan (preparasi mini-DGC pra-freezing);

$\mathrm{p}^{\mathrm{c}}$ : uji t dua sampel bebas data pasca-thawing antara kelompok kontrol dan kelompok perlakuan; *: bermakna jika nilai $\mathrm{p}<0,05$

Viabilitas spermatozoa pasca-thawing juga menurun secara signifikan jika dibanding dengan data viabilitas spermatozoa pra-freezing. Sampel pada kelompok kontrol mempunyai viabilitas spermatozoa pasca-thawing dengan rerata $44,8 \pm 9,4 \%$ sedangkan pada kelompok perlakuan rerata viabilitas pasca-thawing, yaitu sebesar $42,6 \pm 11,1 \%$. Data viabilitas spermatozoa pascathawing pada kedua kelompok ini lebih rendah secara signifikan bila dibandingkan dengan data viabilitas spermatozoa pra-freezing $(\mathrm{p}<0,001)$. Namun, data viabilitas pasca-thawing antara kedua kelompok itu tidak berbeda bermakna $(p=0,503)$.

Persentase morfologi normal spermatozoa pasca-thawing menurun secara signifikan pada kelompok kontrol dari $12 \pm 3,8 \%$ menjadi $9,7 \pm 3,5 \%(\mathrm{p}<0,001)$. Pada kelompok perlakuan, persentase morfologi normal pasca-thawing tidak berbeda bermakna jika dibanding dengan persentase morfologi normal spermatozoa prafreezing $(\mathrm{p}=0,830)$. Persentase morfologi normal pasca-thawing pada kelompok perlakuan lebih tinggi daripada kelompok perlakuan, namun perbedaannya tidak signifikan $(p=0,074)$.

Persentase penurunan kualitas spermatozoa pasca-thawing pada kedua kelompok dianalisis dengan uji t dua sampel bebas. Hasil uji t dapat dilihat pada Tabel 2. Berdasar atas hasil uji $t$, persentase penurunan motilitas (motilitas progresif dan motilitas total) pasca-thawing tidak berbeda bermakna pada kedua kelompok dengan nilai p masing masing 0,422 dan 0,873. Begitu pula dengan persentase penurunan viabilitas spermatozoa pasca-thawing pada kedua kelompok juga tidak berbeda bermakna dengan nilai $\mathrm{p}=0,432$. Penurunan persentase morfologi normal spermatozoa yang lebih besar terdapat

\section{Tabel 2 Penurunan Kualitas Spermatozoa Pasca-thawing pada Kelompok Kontrol dan Kelompok Preparasi (dalam Persen)}

\begin{tabular}{lccc}
\hline \multicolumn{1}{c}{ Parameter } & Kelompok Kontrol & $\begin{array}{c}\text { Kelompok Preparasi Mini- } \\
\text { DGC Pra-freezing }\end{array}$ & Nilai p* $^{*}$ \\
\hline Motilitas progresif (PR) & $52,1 \pm 15,8$ & $56,1 \pm 15,3$ & 0,422 \\
Motilitas total (TM) & $35,4 \pm 13,9$ & $34,6 \pm 15,6$ & 0,873 \\
Viabilitas & $36,5 \pm 13,3$ & $39,9 \pm 13,7$ & 0,432 \\
Morfologi normal & $22,9 \pm 19,8$ & $0,2 \pm 17,8$ & $<0,001^{*}$ \\
\hline
\end{tabular}

Keterangan: *: uji t dua sampel bebas antara kelompok kontrol dan kelompok perlakuan (preparasi mini-DGC prafreezing), bermakna jika nilai $\mathrm{p}<0,05$ 
pada kelompok kontrol bila dibanding dengan kelompok perlakuan. Perbedaan penurunan persentase morfologi normal spermatozoa pada kedua kelompok sangat signifikan( $(p<0,001)$.

\section{Pembahasan}

Proses freezing dan thawing selama proses kriopreservasi mampu merusak struktural dan fungsional spermatozoa, yaitu merusak membran sel spermatozoa ${ }^{4,12}$ sehingga mampu mengubah parameter dari spermatozoa pascathawing, antara lain penurunan motilitas, viabilitas, serta persentase morfologi normal spermatozoa ${ }^{6,7}$ Hasil penelitian ini telah sesuai dengan pernyataan tersebut.

Ozkavukcu dkk ${ }^{13}$ pada penelitiannya telah menyimpulkan bahwa kriopreservasi memiliki pengaruh terhadap parameter spermatozoa, yakni penurunan motilitas, penurunan viabilitas, serta penurunan persentase spermatozoa dengan morfologi normal. Pada pengamatan dengan mikroskop cahaya, spermatozoa pascathawing memperlihatkan perubahan morfologi terutama pada ekor. Persentase spermatozoa dengan ekor yang abnormal khususnya coiled tail meningkat secara signifikan pasca-thawing. Di samping itu, morfologi kepala spermatozoa juga mengalami abnormalitas pasca-thawing. Persentase spermatozoa dengan gangguan akrosom serta subacrosomal swelling meningkat setelah thawing. Pada penelitian ini, dapat diamati peningkatan jumlah spermatozoa dengan ekor dan akrosom yang abnormal setelah proses kriopreservasi.

Kerusakan spermatozoa akibat kriopreservasi disebabkan oleh beberapa mekanisme, antara lain pembentukan kristal es intraseluler dan ekstraseluler, dehidrasi seluler, syok osmotik, serta stres oksidatif. Kristal es intraseluler yang terbentuk misalnya, mampu merusak membran sel spermatozoa serta dapat merusak organel sel sehingga akan memengaruhi survival spermatozoa pasca-thawing. ${ }^{4,6}$

Persentase penurunan kualitas spermatozoa pasca-thawing pada kedua kelompok, yakni kelompok kontrol dan kelompok perlakuan tidaklah berbeda bermakna untuk parameter motilitas serta viabilitas. Hal ini sesuai dengan penelitian Fabozzi dkk. ${ }^{12}$ yang menunjukkan bahwa kedua protokol preparasi semen dalam kriopreservasi baik itu protokol direct freezing maupun protokol preparasi semen sebelum kriopreservasi telah menghasilkan spermatozoa pasca-thawing dengan motilitas yang sebanding.
Donnelly dkk. ${ }^{5}$ di dalam penelitiannya telah menyimpulkan, kriopreservasi spermatozoa dalam plasma semen tanpa proses preparasi semen (protokol direct freezing) memberikan kualitas spermatozoa pasca-thawing dengan motilitas serta integritas DNA yang lebih baik daripada protokol preparasi semen sebelum freezing. Namun, penelitian lain yang dilakukan oleh Petyim dkk. ${ }^{6}$ dan Brugnon dkk. ${ }^{14}$ memberikan hasil yang berbeda. Brugnon dkk. ${ }^{14}$ melaporkan bahwa DGC yang dilakukan sebelum proses freezing meningkatkan kualitas spermatozoa pasca-thawing pada semen pria infertil dengan oligoastenoteratozoospermia. Petyim dkk. ${ }^{6}$ juga sudah menyimpulkan bahwa preparasi semen sebelum proses freezing meningkatkan motilitas spermatozoa pascathawing serta mengurangi jumlah spermatozoa yang mengalami apoptosis apabila dibanding dengan preparasi semen pasca-thawing. Hasil penelitian yang beragam mengenai efektivitas preparasi semen terhadap kualitas spermatozoa pasca-thawing ini disebabkan protokol freezing dan thawing yang berbeda serta penggunaan bahan krioprotektan yang tidak seragam.

Saat ini teknik rapid freezing lebih umum digunakan untuk kriopreservasi spermatozoa karena cukup sederhana bila dibanding dengan slow freezing. Krioprotektan yang digunakan pada penelitian ini adalah SpermFreeze ${ }^{T M}$ juga menggunakan teknik rapid freezing. Teknik freezing yang paling mutakhir, yakni vitrifikasi, meskipun tampak sangat sederhana, namun sejauh ini tidak cukup efektif untuk spermatozoa dikarenakan teknik vitrifikasi yang ada saat ini belum sangat cepat membekukan spermatozoa hingga tercapai keadaan ter-vitrifikasi (glass-like structure). ${ }^{1}$

Pada penelitian ini didapatkan hasil yang menarik, yakni penurunan persentase morfologi normal spermatozoa pasca-thawing pada kelompok perlakuan, yaitu protokol preparasi mini DGC pra-freezing yang jauh lebih rendah apabila dibanding dengan kelompok kontrol dan perbedaannya cukup bermakna. Hal ini memperlihatkan bahwa freezing spermatozoa menggunakan semen yang telah dipreparasi memberikan hasil spermatozoa pasca-thawing yang mempunyai persentase morfologi normal lebih baik bila dibanding dengan spermatozoa pasca-thawing pada protokol direct freezing.

Preparasi semen merupakan suatu teknik seleksi yang memiliki tujuan menuai populasi spermatozoa fungsional dari cairan ejakulat. ${ }^{11,15,16}$ Meskipun terdapat beberapa teknik preparasi semen, teknik swim up dan DGC merupakan dua 
teknik yang umum digunakan. Pemilihan teknik preparasi semen disesuaikan dengan kualitas spermatozoa dalam cairan ejakulat. Pada pasien pria infertil dengan kualitas spermatozoa yang suboptimal, teknik DGC lebih sering digunakan. ${ }^{11}$ Teknik preparasi semen dengan metode DGC telah mampu menghasilkan tuaian spermatozoa dengan motilitas serta morfologi yang baik. ${ }^{10,17}$ Di samping itu, penelitian yang dilakukan oleh Allamaneni dkk. ${ }^{15}$ menunjukkan bahwa preparasi semen dengan teknik DGC lebih efektif daripada swim up baik untuk spermatozoa segar maupun spermatozoa yang telah dikriopreservasi.

Kualitas dari spermatozoa pasca-thawing dipengaruhi oleh beberapa faktor, yakni teknik kriopreservasi (medium krioprotektan yang digunakan, laju penurunan suhu saat freezing, suhu penyimpanan sampel, dan teknik thawing) serta kualitas spermatozoa pra-freezing. ${ }^{8,9}$ Hasil penelitian ini membuktikan bahwa preparasi semen yang dilakukan sebelum proses freezing mampu meningkatkan kualitas spermatozoa pra-freezing sehingga lebih tahan terhadap kerusakan akibat kriopreservasi, khususnya parameter spermatozoa dengan morfologi normal.

Berdasar atas hasil penelitian ini maka dapat disimpulkan kedua protokol kriopreservasi, yakni protokol direct freezing maupun protokol preparasi semen pra-freezing dapat memberikan hasil kualitas spermatozoa pasca-thawing yang sebanding dalam hal motilitas serta viabilitas. Namun, protokol preparasi semen pra-freezing mampu menghasilkan spermatozoa pascathawing yang mempunyai persentase morfologi normal lebih tinggi apabila dibanding dengan protokol direct freezing.

\section{Daftar Pustaka}

1. Mocé E, Fajardo AJ, Graham JK. Human sperm cryopreservation. Eur Med J. 2016;1(1):8691.

2. Di Santo M, Tarozzi N, Nadalini M, Borini A. Human sperm cryopreservation: update on techniques, effects on DNA integrity, and implications for ART. Adv Urol. 2012;2012:112.

3. Vutyavanich $\mathrm{T}$, Lattiwongsakorn $\mathrm{W}$, Piromlertamorn W, Samchimchom S. Repeated vitrification/warming of human sperm gives better results than repeated slow programmable freezing. Asian J Androl. 2012;14(6):850-4.

4. Oberoi B, Kumar S, Talwar P. Study of human sperm motility post cryopreservation. Med J Armed Forces India. 2014;70(4):349-53.

5. Donnelly ET, McClure N, Lewis SEM. Cryopreservation of human semen and prepared sperm: effects on motility parameters and DNA integrity. Fertil Steril. 2001;76(5):892-900.

6. Petyim S, Neungton C, Thanaboonyawat I, Laokirkkiat P, Choavaratana R. Sperm preparation before freezing improves sperm motility and reduces apoptosis in postfreezing-thawing sperm compared with post-thawing sperm preparation. J Assist Reprod Genet. 2014;31(12):1673-80.

7. Boitrelle F, Albert M, Theillac C, Ferfouri F, Bergere M, Vialard F, dkk. Cryopreservation of human spermatozoa decreases the numberof motile normal spermatozoa, induces nuclear vacuolization and chromatin decondensation. J Androl. 2012;33(6):13718.

8. Talwar P. Semen banking and cryobiology. Int J Infertil Fetal Med. 2011;2(2):51-60.

9. Zhang X, Zhou Y, Xia W, Wu H, Yao K, Liu H, dkk. Effect of re-freezing conditions on the progressive motility recovery rate of human frozen spermatozoa. Andrologia. 2012;xx:16.

10. Sharma R, Kattoor AJ, Ghulmiyyah J, Agarwal A. Effect of sperm storage and selection techniques on sperm parameters. Syst Biol Reprod Med. 2015;61(1):1-12.

11. Natali I. Sperm preparation techniques for artificial insemination - comparison of sperm washing, swim up, and density gradient centrifugation methods. Dalam: Manafi M, penyunting. Artificial insemination in farm animals.InTechOpen. 2011. hlm. 115-22.

12. Fabozzi G, Starita MF, Rega E, Alteri A, Colicchia A, Piscitelli C, dkk. Evaluation of the efficiency of two different freezing media and two different protocols to preserve human spermatozoa from cryoinjury. Int J Reprod Med. 2016;2016:6059757.

13. Ozkavukcu S, Erdemli E, Isik A, Oztuna D, Karahuseyinoglu S. Effects of cryopreservation on sperm parameters and ultrastructural morphology of human spermatozoa. J Assist Reprod Genet. 2008; 25(8):403-11.

14. Brugnon F, Ouchchane L, Pons-Rejraji $\mathrm{H}$, Artonne C,Farigoule M, Janny L. Density gradient centrifugation priorto cryopreservation and hypotaurinesupplementation improve postthawquality of sperm from infertile men 
Seso S. Suyono dkk.: Density Gradient Centrifugation Pra-freezing Mengoptimalkan Persentase Morfologi Normal Spermatozoa Pascathawing

with oligoasthenoteratozoospermia. Hum Reprod. 2013;28(8):2045-57.

15. Allamaneni SSR, Agarwal A, Rama S, Ranganathan P, Sharma RK. Comparative study on density gradients and swim-up preparation techniques utilizing neat and cryopreserved spermatozoa. Asian J Androl. 2005;7(1):86-92.

16. Jayaraman V, Upadhya D, Narayan PK, Adiga
SK. Sperm processing by swim-up and density gradient is effective in elimination of sperm with DNA damage. J Assist Reprod Genet. 2012;29(6):557-63.

17. Keskin I, Karabulut S. Effects of density gradient sperm preparation on semen parameters and acrosomal status. Haydarpasa Numune Med J. 2017;57(2):737. 